\title{
Combined perventricular closure of ventricular septal defect and atrial septal defect via lower ministernotomy
}

\author{
Yunfei Ling, Yue Wang, Qiang Fan and Yongjun Qian *
}

\begin{abstract} as lower ministernotomy.

\section{Background}

Ventricular septal defects (VSD) are some of the most frequent congenital heart anomalies, estimated to account for $20-30 \%$ of all congenital cardiac malformations $[1,2]$. In the last decade, perventricular approaches have been successfully applied for the closure of various types of VSD, with promising preliminary results [3-5]. However, to date, no reports are available regarding the combined perventricular closure of VSD and atrial septal defects (ASD) via minimally invasive approaches, such as lower ministernotomy.
\end{abstract}

Background: Minimally invasive approaches such as perventricular closure of ventricular septal defects (VSD) have been applied for the surgical correction of congenital heart defects in order to avoid disadvantages related to median sternotomy with a cardiopulmonary bypass (CPB). However, reports remain scarce regarding combined perventricular closure of VSD and atrial septal defects (ASD) via minimally invasive approaches, such

Results: The authors have operated on 5 patients who were diagnosed with VSD in association with ASD, successfully realizing perventricular closure via lower ministernotomy.

Conclusion: The proposed technique proved to be safe and effective.

Keywords: Ventricular septal defect, Atrial septal defect, Perventricular closure

\section{Methods}

We studied five patients (two boys and three girls) diagnosed with VSD and ASD who underwent operation at the West China Hospital. Answer: We have added the content as follow in the manuscript: All the patients were perimembranous VSD less than $8 \mathrm{~mm}$ that was not adjacent to the conduction bundle and aortic valves and the secundum ASD less than $15 \mathrm{~mm}$. Table 1 presents the baseline data of patients.

\footnotetext{
* Correspondence: qianyongjun@scu.edu.cn

Department of Cardiovascular Surgery, West China Hospital, Sichuan

University, Guoxuexiang 37th, 610041 Chengdu, Sichuan, People's Republic of China
}

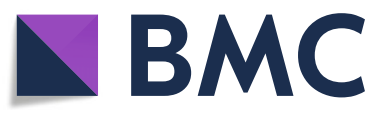

(c) The Author(s). 2018 Open Access This article is distributed under the terms of the Creative Commons Attribution 4.0 International License (http://creativecommons.org/licenses/by/4.0/), which permits unrestricted use, distribution, and reproduction in any medium, provided you give appropriate credit to the original author(s) and the source, provide a link to the Creative Commons license, and indicate if changes were made. The Creative Commons Public Domain Dedication waiver (http://creativecommons.org/publicdomain/zero/1.0/) applies to the data made available in this article, unless otherwise stated. performed under general anaesthesia with a standby cardiopulmonary bypass $(\mathrm{CPB})$ machine available. Following a skin incision of approximately $4-5 \mathrm{~cm}$, a partial lower ministernotomy was performed. After surgical exposure of the anterior free wall of the right ventricle, the optimal puncture site was selected per the routine method. Next, we performed perventricular VSD closure under transoesophageal echocardiographic (TEE) guidance using SQFDQ II and SQFDQ IV occlusion devices (MemoPart VSD Occlusion Device; Lepu Medical Technology, Shanghai Shape Memory Alloy Co., Ltd., Shanghai, China) (Fig. 1a), as described in previous reports [6-8]. Then, a $20 \mathrm{G}$ needle was introduced into the right ventricle, and directed up towards the ASD. Then, a 0.025-in. straight-tipped guide wire was introduced through the needle and maneuvered across the tricuspid valve and ASD into the left atrium. Next, the needle was exchanged with a short $12 \mathrm{~F}$ sheath over the wire (Fig. 1b). Finally, the sheath was positioned across the ASD with its tip in the left atrium, and the ASD occluder was placed (MemoPart ASD Occlusion Device; Lepu Medical Technology, Shanghai Shape Memory Alloy Co., Ltd., Shanghai, China) (Fig. 1c). 
Table 1 Baseline data of patients

\begin{tabular}{lllllll}
\hline $\begin{array}{l}\text { Patient } \\
\text { NO }\end{array}$ & $\begin{array}{l}\text { Age } \\
(\mathrm{month})\end{array}$ & $\begin{array}{l}\text { Weight } \\
(\mathrm{kg})\end{array}$ & $\begin{array}{l}\text { VSD } \\
(\mathrm{mm})\end{array}$ & $\begin{array}{l}\text { ASD } \\
(\mathrm{mm})\end{array}$ & $\begin{array}{l}\text { VSD occluder } \\
(\mathrm{mm})\end{array}$ & $\begin{array}{l}\text { ASD occluder } \\
(\mathrm{mm})\end{array}$ \\
\hline 1 & 19 & 12 & 4 & 6 & 6 & 12 \\
2 & 14 & 10 & 5 & 5 & 7 & 12 \\
3 & 26 & 13 & 6 & 8 & 8 & 14 \\
4 & 18 & 12. & 5 & 7 & 7 & 14 \\
5 & 20 & 12 & 4 & 10 & 7 & 16 \\
\hline
\end{tabular}

VSD ventricular septal defect, $A S D$ atrial septal defect

\section{Results}

Surgery was successful in all patients, with no in-hospital mortality or complications. Mean 'skin-to-skin' time was $62 \pm 31.6 \mathrm{~min}$. No blood infusions or inotropic support were needed in any patient. Mean ventilation support time was $4.2 \pm 6.7 \mathrm{~h}$. No rhythm or atrioventricular conduction disorders occurred. No sternal or rib deformations were observed at the time of discharge, and the small skin incision yielded excellent cosmetic results. Mean hospitalization time was $6.5 \pm 2.8$ days.

\section{Discussion}

Conventionally, most congenital heart defects are treated using $\mathrm{CPB}$ via median sternotomy. With the development of percutaneous interventional techniques, various simple congenital structural heart defects may be repaired with comparable results, possibly providing advantages over conventional surgery in some cases [9]. However, transcatheter shunt closure does not appear to be optimal when the patients present other congenital heart diseases. This new technique should be applied with caution in some subtypes of VSDs like perimembranous VSDs adjacent to the conduction bundle and aortic valves and subarterial VSDs, We did not recommend the eccentric occluder device in the perimembranous VSDs; When the ASDs are too small, the angle through the fourth intercostal space to the ASDs will be hard, another left fourth intercostal space will be recommended to close the ASDs. With improvements in device closure techniques, perventricular device closure of VSD under guidance of transesophageal echocardiography (TEE) has been successfully applied in the surgical correction of congenital defects, with promising preliminary results [4]. Based on this technique, we proposed a new approach for combined perventricular closure of VSD and ASD via lower ministernotomy.

\section{Conclusions}

Compared with conventional surgical repair or femoral transcatheter shunt closure, the advantages of this procedure are obvious. It appears to be safe, associated with less operative trauma, and does not require $\mathrm{CPB}$, fluoroscopy or contrast. In selected patients, perventricular device closure of VSD complicated with ASD is effective, and may either substitute or complement conventional surgical closure.

\section{Abbreviations}

ASD: Atrial septal defect; CPB: Cardiopulmonary bypass; TEE: Transesophageal echocardiography; VSD: Ventricular septal defect

\section{Acknowledgements}

Not applicable

\section{Funding}

The study was supported by the Major Science and Technology Project of Sichuan Province, China (No. 2017SZ0056) and the Scientific Research Project of Sichuan Health and Family Planning Commission, China (No. 17PJ177).

\section{Availability of data and materials \\ Datasets used or analysed during the current study are available from the corresponding author on reasonable request.}

\section{Authors' contributions}

LYF designed the research. LYF and FQ were involved in diagnostic evaluation and surgery. QYJ and WY wrote the paper. All authors read and approved the final manuscript.

\section{Ethics approval and consent to participate Not applicable}

\section{Consent for publication}

The relevant patient provided informed consent for publication of the images in Fig. 1.

\section{Competing interests}

The authors declare that they have no competing interests.

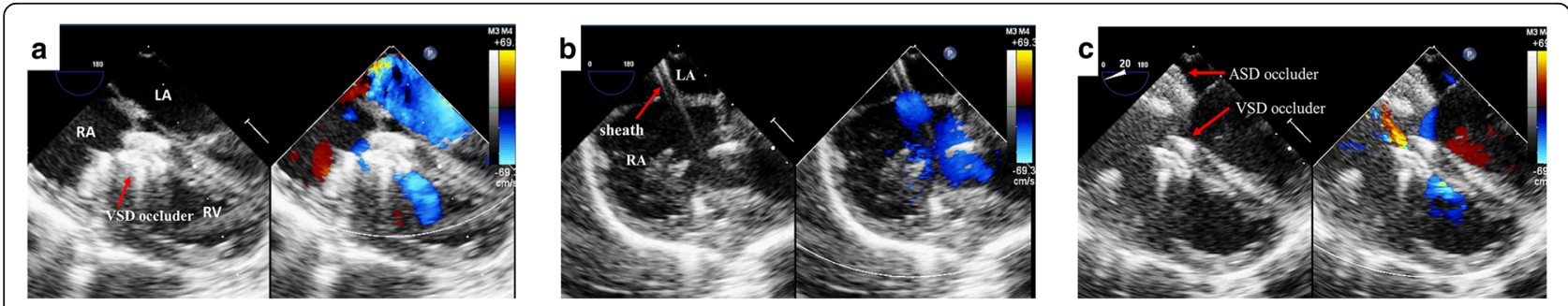

Fig. 1 a Perventricular VSD closure under TEE guidance. $\mathbf{b}$ The $12 \mathrm{~F}$ sheath was positioned across the ASD with its tip in the left atrium. $\mathbf{c}$ ASD occulder was employed under TEE guidance 


\section{Publisher's Note}

Springer Nature remains neutral with regard to jurisdictional claims in published maps and institutional affiliations.

Received: 25 September 2018 Accepted: 3 December 2018

Published online: 12 December 2018

\section{References}

1. Mitchell SC, Korones SB, Berendes HW. Congenital heart disease in 56,109 births. Incidence and natural history. Circulation. 1971;43(3):323-32.

2. Yang J, Yang L, Yu S, et al. Transcatheter versus surgical closure of Perimembranous ventricular septal defects in children : a randomized controlled trial. J Am Coll Cardiol. 2014;63(12):1159-68.

3. Bacha EA, Cao QL, Starr JP, et al. Perventricular device closure of muscular ventricular septal defects on the beating heart: technique and results. J Thorac Cardiovasc Surg. 2003;126(6):1718-23.

4. Gan C, An Q, Lin K, et al. Perventricular device closure of ventricular septal defects: six months results in 30 young children. Ann Thorac Surg. 2008;86(1):142-6.

5. Thakkar B, Patel N, Shah S, et al. Perventricular device closure of isolated muscular ventricular septal defect in infants: a single Centre experience. Indian Heart J. 2012:64(6):559-67.

6. Voitov A, Omelchenko A, Gorbatykh Y, Zaitsev G, Arkhipov A, Soynov I, et al. Outcomes of perventricular off-pump versus conventional closure of ventricular septal defects: a prospective randomized study. Eur J Cardiothorac Surg. 2017:51:980-6.

7. Omelchenko A, Gorbatykh Y, Voitov A, Zaitsev G, Bogachev-Prokophiev A, Karaskov A. Perventricular device closure of ventricular septal defects: results in patients less than 1 year of age. Interact Cardiovasc Thorac Surg. 2016;22:53-6.

8. Yin S, Zhu D, Lin K, An Q. Perventricular device closure of congenital ventricular septal defects. J Card Surg. 2014;29:390-400. https://doi.org/ 10.1111/jocs.12334.

9. Mavroudis C, Backer CL. Pediatric cardiac surgery. 4th ed. UK: Wiley Blackwell; 2013. p. 311-41.

Ready to submit your research? Choose BMC and benefit from:

- fast, convenient online submission

- thorough peer review by experienced researchers in your field

- rapid publication on acceptance

- support for research data, including large and complex data types

- gold Open Access which fosters wider collaboration and increased citations

- maximum visibility for your research: over $100 \mathrm{M}$ website views per year

At BMC, research is always in progress.

Learn more biomedcentral.com/submissions 